\title{
ANALYSIS OF PULSATION OF THE SLIDING-VANE PUMP FOR SELECTED SETTINGS OF HYDROSTATIC SYSTEM
}

\section{ANALIZA PULSACJI CIŚNIENIA POMPY ŁOPATKOWEJ DLA WYBRANYCH NASTAW PARAMETRÓW UKŁADU HYDROSTATYCZNEGO*}

\begin{abstract}
Sliding-vane pumps are widely used as sources of the flow in hydrostatic power transmission systems. A noticeable tendency in hydrostatic systems is revealed in the form of minimization of the mass, overall dimensions and at the same time increasing of a power density delivered by pumps. The article presents the preliminary results of the studies related to a pressure pulsation of the hydraulic system equipped with the sliding-vane pump (T7BS type manufactured by Parker \& Denison Company). During the studies the pressure pulsation in selected places of pressure line were recorded. A series of measurements were performed for selected settings of the system. The recorded characteristics were analysed in time and frequency domains.
\end{abstract}

Keywords: vane pump, pressure pulsation, hydrostatic drive.

\begin{abstract}
Pompy topatkowe należa do często używanych generatorów strugi cieczy roboczej w napędach hydrostatycznych. Zauważalna tendencją w opisywanych układach jest minimalizacja masy oraz wymiarów gabarytowych, przy jednoczesnym zwiększaniu gęstości mocy oferowanej przez pompę. W artykule przedstawiono wyniki wstępnych badań hydraulicznego napędu hydrostatycznego z pompa typu T7BS firmy Parker \& Denison. Podczas badań zarejestrowano wartości pulsacji ciśnienia w wybranych miejscach linii tłocznej. Cykl pomiarów przeprowadzono w odniesieniu do wybranych nastaw pracy uktadu. Uzyskane przebiegi zostaty przeanalizowane w dziedzinach czasu oraz częstotliwości.
\end{abstract}

Slowa kluczowe: pompa topatkowa, pulsacja ciśnienia, napęd hydrostatyczny.

\section{Introduction}

Despite significant progress in the development of hydraulic drive systems, users of the systems fitted with hydrostatic drives [1, 17] still experience a number of displacement pump failures. The process of diagnosing such devices is complicated and requires applying advanced tools $[2,5]$ or data processing algorithms. Additionally most of these devices are not diagnose susceptible $[3,18]$, what results from operating conditions [6] and external interferences.

Displacement pump diagnostic methods include vibroacoustic techniques, flow and pressure measurements, temperature control etc. However, each of those methods has its limitations and requires extensive knowledge [20-22].

The most commonly measured parameter of the hydrostatic systems is pressure [4]. Based on the analysis of phenomena relating to displacement pump pressure pulsation, it is possible to determine a number of system operating parameters demonstrating failures $[7,10$, $12,16]$ or detuning. Vibration due to pressure pulsation is caused by the uneven flow of hydraulic fluid from the pump to the system, which results in the accelerated wear of pump's elements [13, 14], increased emission of noise and reduction in the accuracy of the receivers' positioning. In the experiment presented in this article, the analysis of pressure pulsation in the discharge line was performed on the Parker \& Denison T7BS rotary vane pump and the results have been compared with the simulation carried out on the proprietary model.
2. Mathematical and simulation models of the rotary vane pump efficiency

Figure 1 presents the operating diagram of a single acting rotary vane pump. Temporary efficiency [19] of a pump results from the infinitesimal area circled by the vanes of a pump during the phase of crossing the transitory zone between the suction and discharge zones.

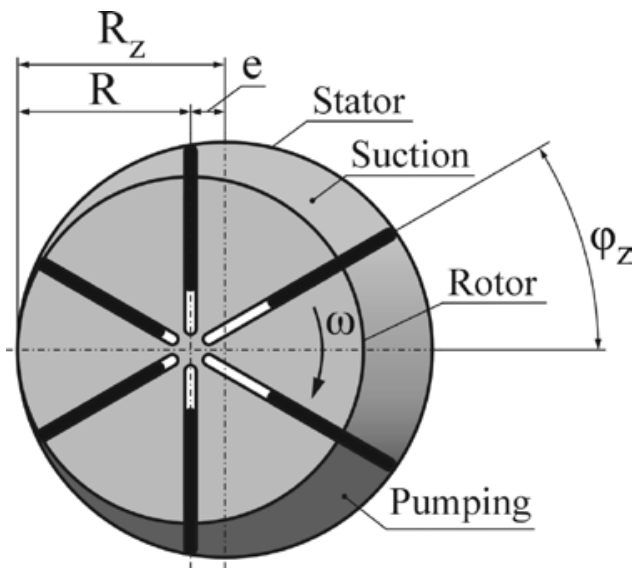

Fig. 1. Operating diagram of a single acting rotary vane pump

(*) Tekst artykułu w polskiej wersji językowej dostępny w elektronicznym wydaniu kwartalnika na stronie www.ein.org.pl 
In order to derive the formula to calculate temporary efficiency of the considered pump, the following simplifying assumptions have been adopted:

- outline of the stator track (in the form of a perfect circle),

- transverse dimensions of a pump vane (zero thickness),

- coordinate system - polar coordinate system has been adopted for the analysis (with the pole placed in the axis of the rotor revolution),

- motion of the fluid - raising the fluid while the vanes travel from suction to discharge zone.

In relation to the adopted assumptions, efficiency of the pump has been determined as the capacity between two temporary positions of the vane in the transitory zone:

$$
q=\frac{B}{d t}\left(d A-d A_{u}\right)
$$

where: B - width of the vane of the considered pump $[\mathrm{m}]$,

$\mathrm{dA}$ - temporary area circled by the vane while travelling from suction to discharge zone $\left[\mathrm{m}^{2}\right]$, $\mathrm{dA}_{\mathrm{u}}$ - temporary area circled by the opposite vane travelling from discharge to suction zone $\left[\mathrm{m}^{2}\right]$.

The relation defining the value of temporary area circled by the vane travelling from suction to discharge zoned A, described in the polar coordinate system, takes the following form:

$$
d A=0,5\left(r^{2}-R^{2}\right) d \varphi \rightarrow d A=0,5 \omega\left(r_{z}^{2}-R^{2}\right) d t
$$

where: $r_{z}-$ temporary radius of the point of contact between the vane and stator track $[\mathrm{m}]$,

$\mathrm{R}$ - pumprotor radius $[\mathrm{m}]$,

$\omega-$ rotor angular speed $[\mathrm{rad} / \mathrm{s}]$.

The relation enabling determination of the area circled by the opposite vane will take the same form as equation 2 , with the only difference being other radius of the contact between the vane and track. After inserting equation 2 in the equation 1 , the following formula for the pump temporary efficiency has been obtained:

$$
q=0,5 B \omega\left(r_{z}^{2}-r_{u}^{2}\right)
$$

where: $r_{u}$ - radius of the contact of the opposite vane travelling from discharge to suction zone [m].

Temporary radii of the pump vanes' contact may be expressed as:

$$
\begin{gathered}
r_{z}^{2}-2 e r_{z} \cos \varphi+e^{2}-R_{z}^{2}=0 \\
r_{u}^{2}-2 e r_{u} \cos \cos (\varphi-\pi)+e^{2}-R_{z}^{2}=0
\end{gathered}
$$

where: $\mathrm{e}$ - pump eccentricity [m].

Taking into consideration the conditions determined using formula 3 , the equation identifying the values of temporary radii of pump vanes' contact is as follows:

$$
q=0,5 B \omega\left[\left(e \cos \phi+\left(e^{2}\left(\cos ^{2} \phi-1\right)+R_{Z}^{2}\right)^{0,5}\right)-\left(e \cos (\phi-\pi)+\left(e^{2}\left(\cos ^{2}(\phi-\pi)-1\right)+R_{Z}^{2}\right)^{0,5}\right)\right]
$$

where: $\varphi$ - temporary angular position of the vane in the transitory zone from suction to discharge.

Having considered that angle $\varphi$ changes within the range $(-\pi / z \div \pi / z)$, where $z$ stands for the number of vanes, theoretical flow output of the single acting rotary vane pump with 12 vanes may be presented in the form of the characteristics shown in Fig. 2.

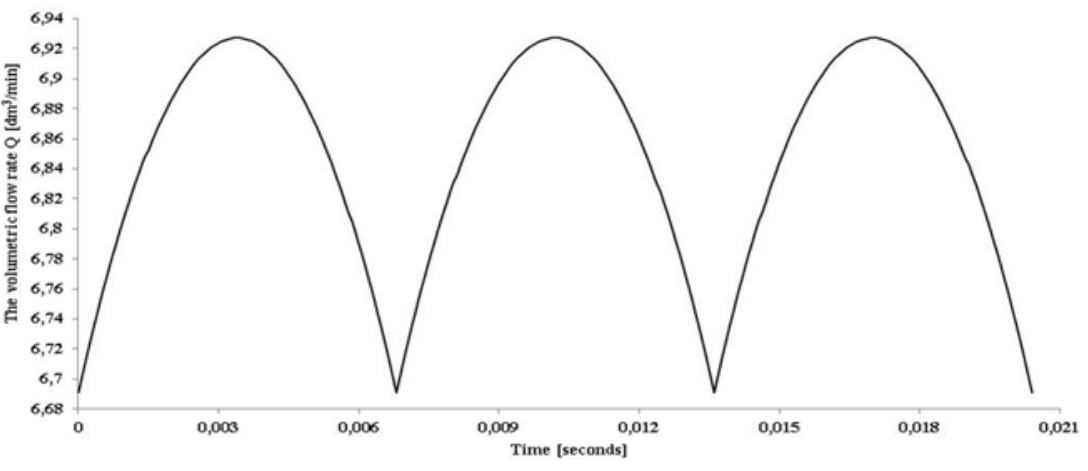

Fig. 2. Diagram of the theoretical temporary pulsation of a rotary vane pump with 12 vanes (vane width $60 \mathrm{~mm}$, stator track diameter $160 \mathrm{~mm}$, eccentricity value $25 \mathrm{~mm}$, rotational speed of the pump shaft $n_{n}=735 \mathrm{rpm}$ )

In case of the considered pump, the irregularity of efficiency, obtained based on the developed mathematical model, was 3,45\%.

The acquired simulation characteristics of the flow output of the pump have been implemented in the measurement system model $[8,9$,

Fig. 3. Measurement system model in the Matlab-Simulink environment

15], developed in the Matlab-Simulink environment (Fig. 3). The suction line (between the source of stream and maximum valve)has been modeled as the collection of modules consisting of Simscape Hydraulic library function blocks oriented for the purposes of the simulation: hydraulic resistance of the supply bus, capacity of the hydraulic hose and fluid inertia in the hose $[11,23]$.

The simulation has been carried out in relation to two selected cases (Fig. 4), with the adopted rotational speedn $_{n}$ of the pump shaft of $735 \mathrm{rpm}$ :

- discharge line with no extra capacity,

- discharge line with extra capacity of the hydraulic fluid.

Values of the pressure pulsation obtained as a result of the simulation and laboratory measurements suggest the proper selection of parameters for the adopted model. The simulation characteristics do not reflect the impact of the maximum valve dynamics on the examined 
a) 60,8

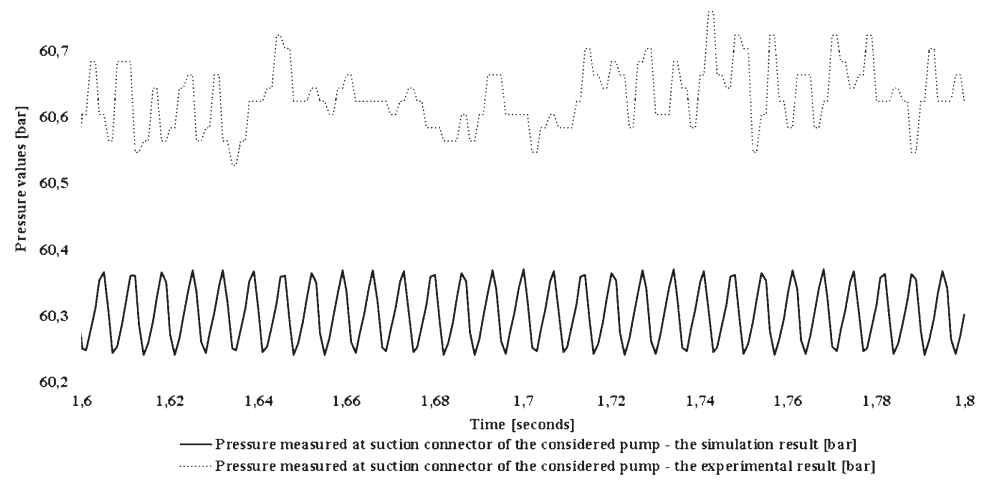

b) 60,52

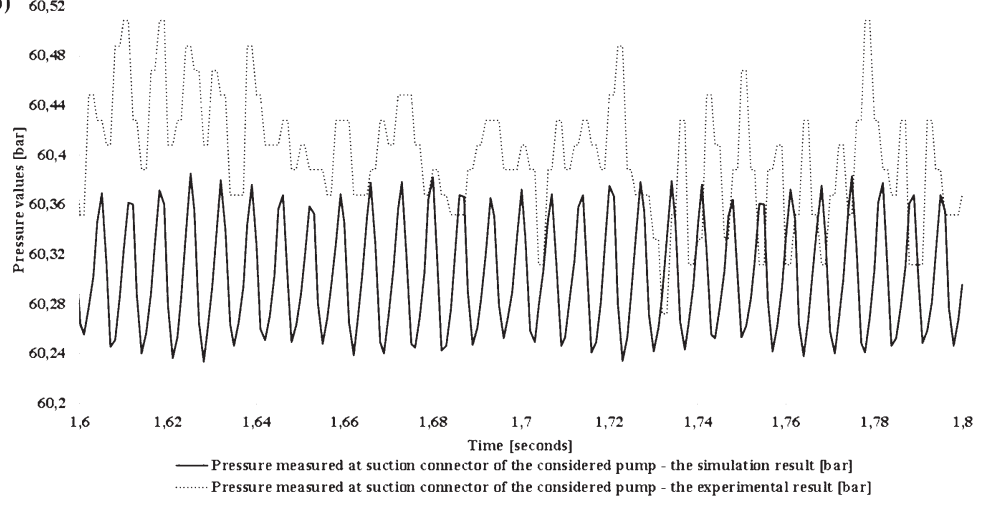

Fig. 4. Characteristics of pressure pulsation obtained as a result of experimental tests and simulation $\left(n_{n}=735 \mathrm{rpm}, p_{s}=60\right.$ bar, temperaturets $\left.=40^{\circ} \mathrm{C}\right):$ a) with no extra capacitance of the discharge line, b) with extra capacitance of the discharge line

phenomenon, which is the result of the limitations of function block used to model maximum valve.

\section{Measuring station and experiment plan}

Measuring system (Fig. 5) consists of the double acting rotary vane pump (T7BS B09 3R00 A1M0 manufactured by Parker \& Denison) powered by the $\mathrm{AC}$ asynchronous motor with frequency con-

Table 1. Parameters of the experiment

\begin{tabular}{|c|c|c|c|c|}
\hline $\begin{array}{l}\text { Designation } \\
\text { ofresearch }\end{array}$ & $\begin{array}{l}\text { Extra ca- } \\
\text { pacitance }\end{array}$ & $\begin{array}{l}\text { Speedof the pump shaftn } \\
\text { [rpm] }\end{array}$ & $\begin{array}{l}\text { Forcing pressure setting } \\
\qquad p_{s}[\text { bar }]\end{array}$ & $\begin{array}{c}\text { Oiltemperature } \\
t_{s}\left[{ }^{\circ} \mathrm{C}\right]\end{array}$ \\
\hline P1 & No & \multirow{2}{*}{730} & \multirow{2}{*}{60} & \multirow{8}{*}{25} \\
\hline P2 & Yes & & & \\
\hline P3 & No & \multirow{2}{*}{735} & \multirow{4}{*}{120} & \\
\hline P4 & Yes & & & \\
\hline P5 & No & \multirow{2}{*}{1441} & & \\
\hline P6 & Yes & & & \\
\hline P7 & No & \multirow{2}{*}{1455} & \multirow{4}{*}{60} & \\
\hline P8 & Yes & & & \\
\hline$P_{-} 1$ & No & \multirow{2}{*}{730} & & \multirow{8}{*}{40} \\
\hline P_2 & Yes & & & \\
\hline P_3 & No & \multirow{2}{*}{735} & \multirow{4}{*}{120} & \\
\hline P_4 & Yes & & & \\
\hline P_5 & No & \multirow{2}{*}{1441} & & \\
\hline P_6 & Yes & & & \\
\hline P_7 & No & \multirow{2}{*}{1455} & \multirow{2}{*}{60} & \\
\hline P_8 & Yes & & & \\
\hline
\end{tabular}

HMRALU: CYNOERS

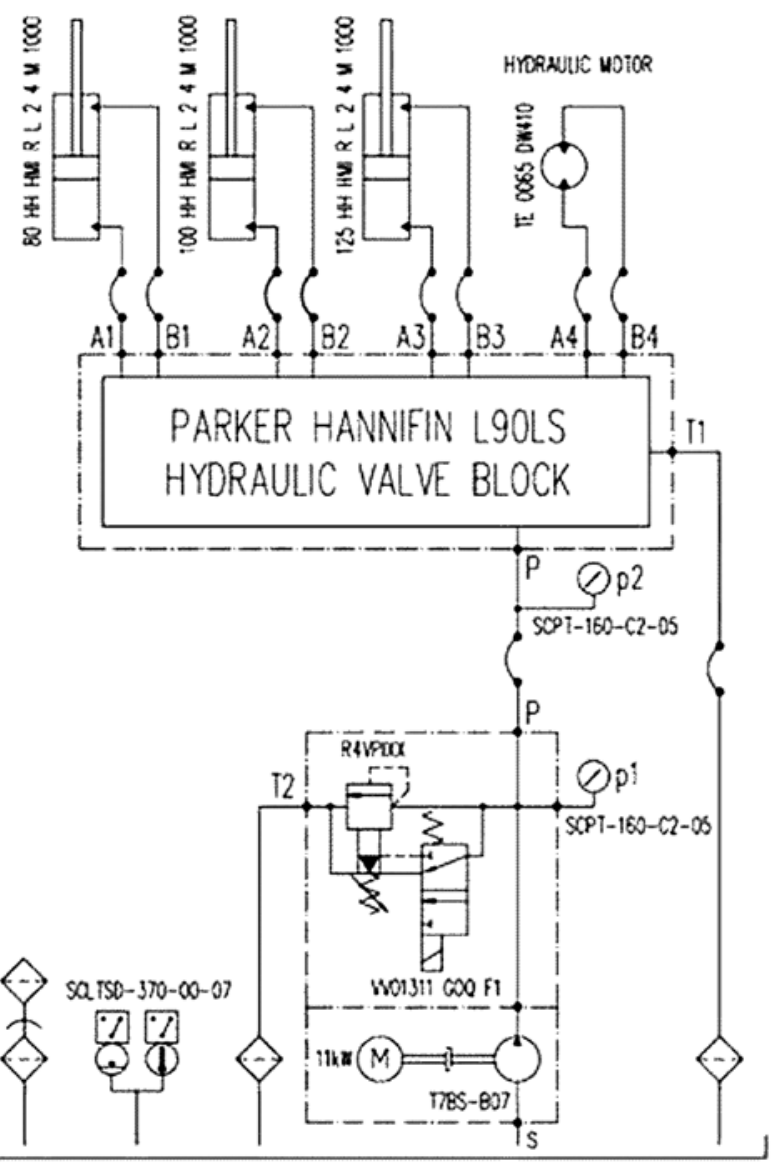

Fig. 5. Schematic diagramofthestation used to examinepulsationandvibration of the rotary vane pump

verter, L90LS valve block and receivers (hydraulic rotary motor and three hydraulic cylinders).

The pump has been connected with the valve block by means of the elastic discharge pipe of the following parameters: internal diameter $\mathrm{d}_{\mathrm{w}}=16 \mathrm{~mm}\left(5 / 8^{\prime \prime}\right)$, two steel braids (type 2SN), hose length $5 \mathrm{~m}$. Pressure sensors SCPT-160-C2-05 have been installed at the pressure flange and before the valve block. Additionally, a flow meter SCFT060-C2-05has been installed before the valve block. Working fluid temperature was monitored using temperature sensor SCLTSD-370-00-07, installed in the oil tank. Results were monitored and saved using ServiceMaster Plus instrument.

Measurements were taken according to Table 1. Variable parameters included pressure and rotational speed of the pump shaft (regulation of the volumetric flow rate).

\section{Station-based testing}

Operating principle of displacement pumps involving periodical changes in the capacity of working areas is the reason of flow output and the pumping pressure fluctuation connected with temporary efficiency. Only screw pumps are free from this defect. 
The examined pump T7BS B09 3R00 A1M0 from Parker \& Denison is a double acting rotary vane pump with fixed efficiency. Such construction enables relieving the pump shaft from the impact of axial forces coming from the pumping pressure and doubling the efficiency(as compared with the single acting rotary vane pump of the similar size).

As far as pump T7BS is concerned, the rotor is fitted with 12 vanes, and therefore the frequency of vanes travelling from the suction to discharge zone, equal with the frequency of the expected flow output of the pump $f_{p}$, is as follows:

$$
f_{p}=\frac{i \cdot n}{60}[\mathrm{~Hz}]
$$

where: $i-$ a number of vanes,

$n$ - rotational speed of the pump shaft [rpm].

Table 2 summarizes the expected values of the pressure peak frequency, resulting from rotation of the pump shaft $\left(f_{n}\right)$ and the subsequent vanes entering the discharge phase $\left(f_{p}\right)$.

Table 2. Expected values of the characteristic frequencies

\begin{tabular}{|c|c|c|c|c|c|c|}
\hline $\begin{array}{c}\text { Designation } \\
\text { of study }\end{array}$ & $\begin{array}{l}\text { Extra ca- } \\
\text { pacitance }\end{array}$ & $\mathrm{n}_{\mathrm{n}}[\mathrm{rpm}]$ & $f_{n}[\mathrm{~Hz}]$ & $\begin{array}{c}\text { I-stharmonic } \\
\mathrm{f}_{\mathrm{n} \_1 \mathrm{st}}[\mathrm{Hz}]\end{array}$ & $\mathrm{f}_{\mathrm{p}}[\mathrm{Hz}]$ & $\begin{array}{c}\text { I-stharmonic } \\
\mathrm{f}_{\mathrm{p}_{-} 1 \mathrm{st}}[\mathrm{Hz}]\end{array}$ \\
\hline P1 & No & 730 & 12,2 & 24,3 & 146,0 & 292,0 \\
\hline P2 & Yes & 730 & 12,2 & 24,3 & 146,0 & 292,0 \\
\hline P3 & No & 735 & \multirow{2}{*}{\multicolumn{4}{|c|}{$\begin{array}{l}\text { Hydraulicpower supply overload at setparameters } \\
\text { (inability to achieve a pressure of } p_{s}=120 \text { bar) }\end{array}$}} \\
\hline P4 & Yes & 735 & & & & \\
\hline P5 & No & 1441 & 24,0 & 48,0 & 288,2 & 576,4 \\
\hline P6 & Yes & 1441 & 24,0 & 48,0 & 288,2 & 576,4 \\
\hline P7 & No & 1455 & 24,3 & 48,5 & 291,0 & 582,0 \\
\hline P8 & Yes & 1455 & 24,3 & 48,5 & 291,0 & 582,0 \\
\hline P_1 & No & 730 & 12,2 & 24,3 & 146,0 & 292,0 \\
\hline P_2 & Yes & 730 & 12,2 & 24,3 & 146,0 & 292,0 \\
\hline P_3 & No & 735 & \multirow{2}{*}{\multicolumn{4}{|c|}{$\begin{array}{l}\text { Hydraulic power supply overload at setparameters } \\
\text { (inability to achieve a pressure of } p_{s}=120 \text { bar) }\end{array}$}} \\
\hline P_4 & Yes & 735 & & & & \\
\hline P_5 & No & 1441 & 24,0 & 48,0 & 288,2 & 576,4 \\
\hline P_6 & Yes & 1441 & 24,0 & 48,0 & 288,2 & 576,4 \\
\hline P_7 & No & 1455 & 24,3 & 48,5 & 291,0 & 582,0 \\
\hline P_8 & Yes & 1455 & 24,3 & 48,5 & 291,0 & 582,0 \\
\hline
\end{tabular}

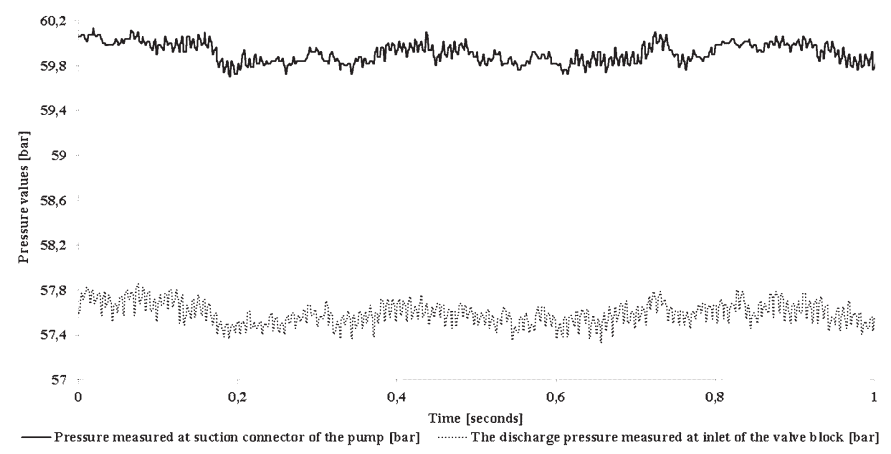

Fig. 6. 'Time courses of the pressure values with low rotational speed of the pump with no extra capacitance (experiment $P 1-$ Tab. $1, n_{n}=735 \mathrm{rpm}$, $\left.t_{\mathrm{s}}=25^{\circ} \mathrm{C}, p_{\mathrm{s}}=60 \mathrm{bar}\right)$
61,2

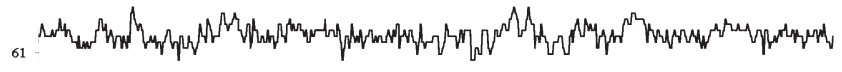

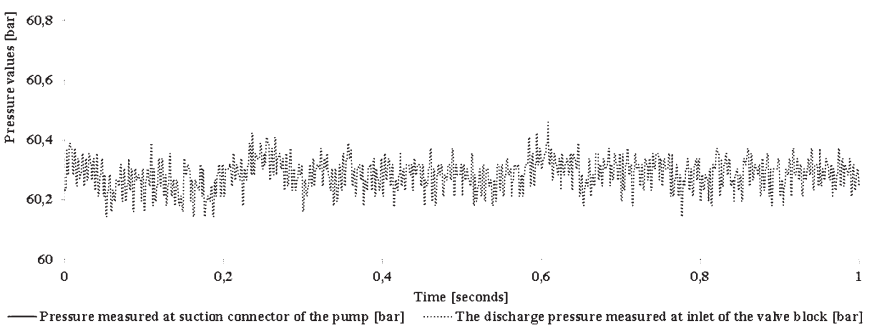

Fig. 7. Time courses of the pressure values with fast rotational speed of the pump with no extra capacitance (experiment P7 - Tab. 1, $n_{n}=1470$ rpm, $t_{s}=25^{\circ} \mathrm{C}, p_{s}=60 \mathrm{bar}$ )

Summary results of measuring pressure on the discharge line of the pump were presented in the time (Table 3 ) and frequency domains (Table 4).

Besides the pulsation triggered by the pump vanes travelling from suction to discharge zone, in frequency spectrums one can notice (Fig. 10-13) pump shaft rotation frequency and its first harmonic (the reason is eccentricity of the pump shaft in relation to the stator ring track). Juxtaposition of pressure values in the time and frequency domains was presented in Tables 3 and 4.

Furthermore, peak-to-peak value of the pressure measured by the pump is significantly lower than peak-to-peak value of pressure measured by the valve block (L90LS). What's more, in frequency spectrums measured by the valve block, one can observe pressure fluctuations that are almost invisible in the pressure spectrums by the pump.

The reason of the phenomenon connected with the occurrence of additional frequencies is a maximum valve installed in the block L90LS. During measurements, the stream provided by the examined pump to the block L90LS, was flowing through two-stage maximum valve to the discharge pipe line and then to the tank. Operating characteristics of maximum valve, where the main stage poppet operates with variable valve opening, causes self-excited pressure pulsation in case of the valve with not sufficient damping of poppet vibration. In the described case, it is maximum valve that is responsible for the additional pressure pulsation. The sampling frequency of recorded signals amounted to $1000 \mathrm{~Hz}$. At the data processing method the authors adopted 2048 FFT samples analyzed with

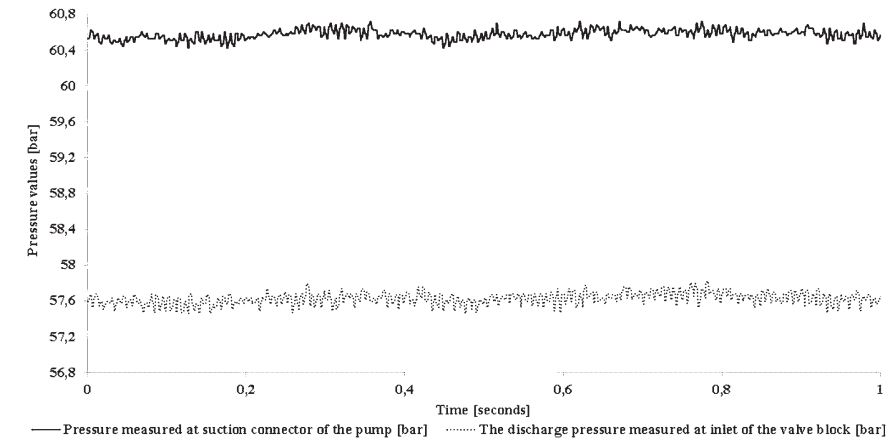

Fig. 8. Time courses of the pressure values with low rotational speed of the pump with no extra capacitance (experiment $P 1-$ Tab. $1, n_{n}=735$ $\mathrm{rpm}, t_{\mathrm{s}}=40^{\circ} \mathrm{C}, p_{\mathrm{s}}=60 \mathrm{bar}$ )

a function of the Flat Top window. Frequency spectrums were subjected to averaging in a domain of the four groups of samples. Due 


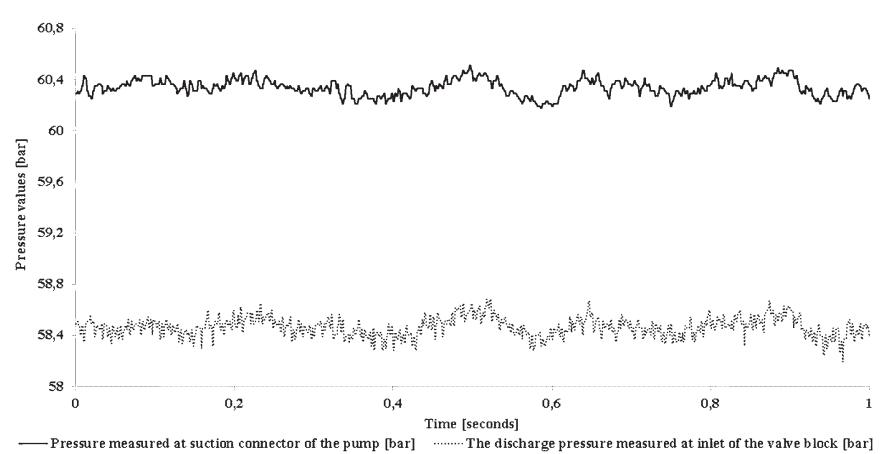

Fig. 9. Time courses of the pressure values with fast rotational speed of the pump with no extra capacitance (experiment $P_{-} 7-$ Tab. $1, n_{n}=1470$ rpm, $t_{s}=40^{\circ} \mathrm{C}, p_{s}=60 \mathrm{bar}$ )

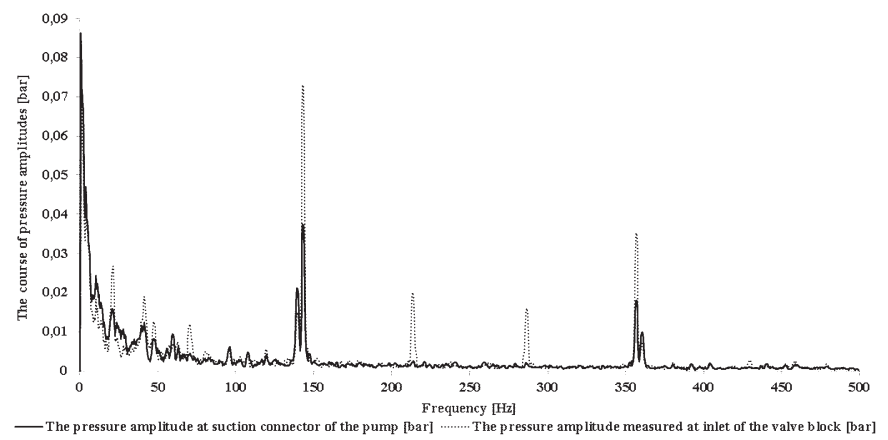

Fig. 10. Frequency spectrums of pressure frequencies with low rotational speed of the pump with no extra capacitance (experiment P1 - Tab. 1, $n_{n}=735 \mathrm{rpm}, t_{s}=25^{\circ} \mathrm{C}, p_{s}=60 \mathrm{bar}$ )

0,05

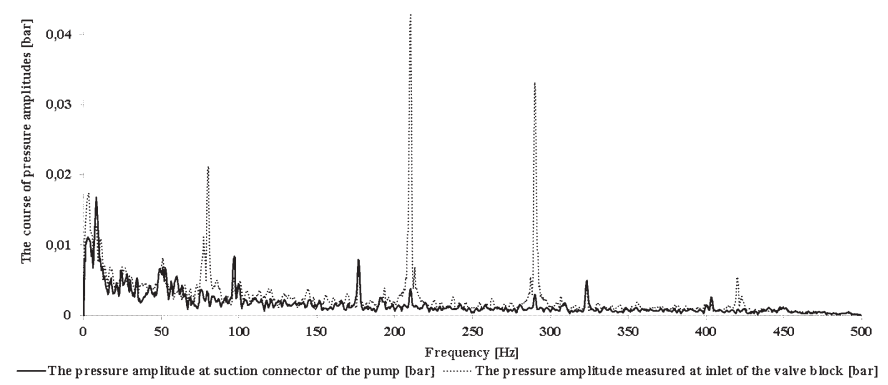

Fig. 11. Frequency spectrums of pressure frequencies with fast rotational speed of the pump with no extra capacitance (experiment P7 - Tab. 1, $\left.n_{n}=1470 \mathrm{rpm}, t_{s}=25^{\circ} \mathrm{C}, p_{s}=60 \mathrm{bar}\right)$

to limitations of the measurement device recording the first harmonic responsible for entering successive blades in the discharge phase $f_{p}$ at high speeds was not possible (Table 4).

As can be observed, a factor that has strong influence on pressure pulsation amplitudes resulting from eccentricity (frequencyf $f_{n}$ ) is temperature, and at the same time hydraulic fluid viscosity. Pulsation amplitude resulting from the fact of vanes entering discharge zone is much lower. Additionally, it may be noticed (Table 4) that low frequency of pressure pulsation $\mathrm{f}_{\mathrm{n}}$ (circa $12 \mathrm{~Hz}$ ) is damped by the hose connecting the pump with valve block.

Amplitudes of pressure pulsation resulting from the fact of vanes entering discharge zone $\left(f_{p}\right)$ are several times lower;one may, however, notice their reinforcement by the discharge line.

In case of higher rotational speed of the pump shaft, one may observe strengthening of pressure pulsation at the discharge line between the pump and valve block not only in case of frequencyf $f_{p}$, but also frequencyf $f_{n}$ (here equal to circa $24 \mathrm{~Hz}$ ). In the extreme case, 4

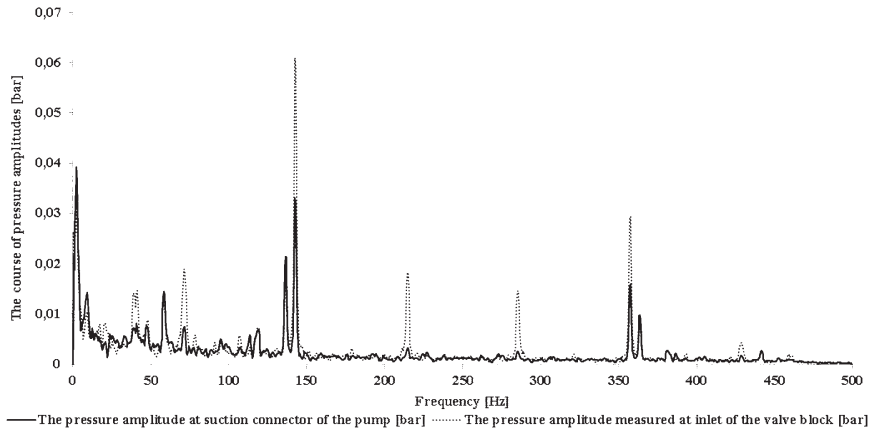

Fig. 12. Frequency spectrums of pressure frequencies with low rotational speed of the pump with no extra capacitance (experiment $P_{-} 1-T a b$. $1, n_{n}=735 \mathrm{rpm}, t_{s}=40^{\circ} \mathrm{C}, p_{s}=60 \mathrm{bar}$ )

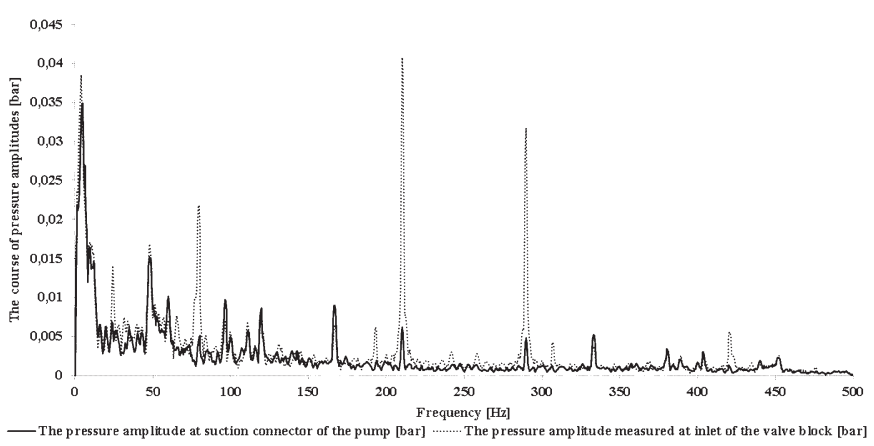

Fig. 13. Frequency spectrums of pressure frequencies with low rotational speed of the pump with no extra capacitance (experiment $P_{-} 7-T a b$. $1, n_{n}=1470 \mathrm{rpm}, t_{s}=40^{\circ} \mathrm{C}, p_{s}=60 \mathrm{bar}$ )

times stronger pressure pulsation of $24 \mathrm{~Hz}$ and 12 times stronger pressure pulsation of $290 \mathrm{~Hz}$.

The impact of discharge pressure on the pulsation amplitude at the pressure flange of the pump (pressure $\mathrm{p}_{1}$ ) is not dominating. Nevertheless, it may be observed that the amplitude of pressure pulsation in relation to the frequency of pump shaft rotation $\mathrm{f}_{\mathrm{n}}$ increases with increase of discharge pressure. It may be a sign of the increase of pump shaft eccentricity, which should not happen taking into consideration its design (double acting pump is fitted with the shaft relieved from the radial forces coming from the discharge pressure).

The obtained results of experimental tests were compared with the respective simulation results (Fig. 4 and Table 5).

Despite discrepancies between the obtained values it should be stated that model tests of the impact of pump pulsation on the measurements of discharge pressure are close to the actual measurements to such extent that it is possible to use them for the process of designing new hydraulic systems. Another stage in the development of a mathematical model will be the process of tuning parameters, in order to develop the diagnostic model based on the pump equations.

\section{Conclusions}

The acquired results are to a large extent compatible with expectations. Due to small irregularities in the efficiency of rotary vane pump (theoretically lower by 3,5\%), the observed pressure pulsation is characterized by low peak-to-peak values, in the worst case not exceeding $0,73 \mathrm{bar}\left(\mathrm{p}_{\mathrm{s}}=120 \mathrm{bar}, \mathrm{n}_{\mathrm{n}}=1441 \mathrm{rpm}, \mathrm{t}_{\mathrm{s}}=40^{\circ} \mathrm{C}\right)$. Spectrum analysis indicates the necessity of paying attention to the relationship between the amplitude of pressure pulsation with the rotation frequency of a pump shaft dependent on the fluid viscosity and discharge pressure.

In case of pressure pulsation, resulting from the periodicity of pump operation, one should focus on the impact of discharge line on the values of its amplitude at the receiver. It results from the strong 
Table 3. Comparison of pressure pulsation values in time domain

\begin{tabular}{|c|c|c|c|c|c|c|}
\hline \multirow{2}{*}{$\begin{array}{l}\text { Designation } \\
\text { ofstudy }\end{array}$} & \multicolumn{3}{|c|}{$\begin{array}{l}\text { Pressure at thepump outlet } \\
\qquad \mathrm{p}_{1}[\mathrm{bar}]\end{array}$} & \multicolumn{3}{|c|}{$\begin{array}{l}\text { Pressureat the inlet of valve block } \\
\left.\qquad \mathrm{p}_{2} \text { [bar }\right]\end{array}$} \\
\hline & $\mathrm{p}_{1 \_\operatorname{MAX}}$ & $\mathrm{p}_{1 \_\mathrm{MIN}}$ & $\mathrm{p}_{1 \_ \text {PTP }}$ & $\mathrm{p}_{2 \_\operatorname{MAX}}$ & $\mathrm{p}_{2 \_\mathrm{MIN}}$ & $\mathrm{p}_{2 \_ \text {PTP }}$ \\
\hline P1 & 60,14 & 59,70 & 0,43 & 57,859 & 57,33 & 0,52 \\
\hline $\mathrm{P} 2$ & 59,96 & 59,55 & 0,41 & 57,615 & 57,14 & 0,47 \\
\hline P3 & \multirow{2}{*}{\multicolumn{6}{|c|}{$\begin{array}{l}\text { Hydraulicpower supplyoverload at setparameters } \\
\text { (inability toachieve apressureof } p_{s}=120 \text { bar) }\end{array}$}} \\
\hline P4 & & & & & & \\
\hline P5 & 119,94 & 119,64 & 0,32 & 115,92 & 115,23 & 0,69 \\
\hline P6 & 119,88 & 119,66 & 0,22 & 115,64 & 115,2 & 0,44 \\
\hline P7 & 61,15 & 60,98 & 0,18 & 60,46 & 60,14 & 0,32 \\
\hline P8 & 61,23 & 61,06 & 0,18 & 60,41 & 60,11 & 0,3 \\
\hline P_1 & 60,72 & 60,43 & 0,3 & 57,82 & 57,46 & 0,37 \\
\hline P_2 & 60,56 & 60,25 & 0,31 & 57,61 & 57,23 & 0,39 \\
\hline P_3 & \multirow{2}{*}{\multicolumn{6}{|c|}{$\begin{array}{l}\text { Hydraulicpower supplyoverload at setparameters } \\
\text { (inability toachieve apressureof } p_{s}=120 \text { bar) }\end{array}$}} \\
\hline P_4 & & & & & & \\
\hline P_5 & 120,19 & 119,76 & 0,436 & 114,75 & 114,03 & 0,73 \\
\hline P_6 & 120,49 & 120,19 & 0,296 & 114,93 & 114,47 & 0,46 \\
\hline P_7 & 60,51 & 60,18 & 0,332 & 58,68 & 58,19 & 0,49 \\
\hline P_8 & 60,58 & 60,37 & 0,216 & 58,74 & 58,41 & 0,33 \\
\hline
\end{tabular}

Table 4. Comparison of pressure pulsation values in frequency domain

\begin{tabular}{|c|c|c|c|c|c|c|c|c|}
\hline \multirow{2}{*}{$\begin{array}{l}\text { Designation } \\
\text { ofstudy }\end{array}$} & \multicolumn{4}{|c|}{$\begin{array}{l}\text { Pressure peaks } p_{1} \text { of the characteristic frequencies } \\
\text { [bar] }\end{array}$} & \multicolumn{4}{|c|}{ Pressure peaks $p_{2}$ of the characteristic frequencies [bar] } \\
\hline & $f_{n}$ & $f_{n_{-} 1 s t}$ & $f_{p}$ & $f_{p_{-} 1 s t}$ & $f_{n}$ & $f_{n_{-} 1 s t}$ & $f_{p}$ & $f_{p_{-} 1 s t}$ \\
\hline P1 & 0,0195 & 0,0111 & 0,0028 & 0,0010 & 0,0110 & 0,0081 & 0,0058 & 0,0010 \\
\hline P2 & 0,0182 & 0,0052 & 0,0021 & 0,0012 & 0,0151 & 0,0070 & 0,0045 & 0,0011 \\
\hline P3 & \multirow{2}{*}{\multicolumn{8}{|c|}{$\begin{array}{l}\text { Hydraulicpower supplyoverload at setparameters } \\
\text { (inability toachieve apressureof } p_{s}=120 \text { bar) }\end{array}$}} \\
\hline P4 & & & & & & & & \\
\hline P5 & 0,0090 & 0,0121 & 0,0016 & - & 0,0199 & 0,0073 & 0,0138 & - \\
\hline P6 & 0,0086 & 0,0120 & 0,0010 & - & 0,0364 & 0,0062 & 0,0072 & - \\
\hline P7 & 0,0064 & 0,0059 & 0,0016 & - & 0,0061 & 0,0054 & 0,0198 & - \\
\hline P8 & 0,0051 & 0,0057 & 0,0017 & - & 0,0067 & 0,0041 & 0,0185 & - \\
\hline P_1 & 0,0069 & 0,0055 & 0,0016 & 0,0010 & 0,0070 & 0,0032 & 0,0037 & 0,0012 \\
\hline P_2 & 0,0055 & 0,0094 & 0,0019 & 0,0010 & 0,0054 & 0,0075 & 0,0037 & 0,0018 \\
\hline P_3 & \multirow{2}{*}{\multicolumn{8}{|c|}{$\begin{array}{l}\text { Hydraulicpower supplyoverload at setparameters } \\
\text { (inability toachieve apressureof } p_{s}=120 \text { bar) }\end{array}$}} \\
\hline P_4 & & & & & & & & \\
\hline P_5 & 0,0054 & 0,0185 & 0,0016 & - & 0,0096 & 0,0110 & 0,0059 & - \\
\hline P_6 & 0,0130 & 0,0172 & 0,0012 & - & 0,0323 & 0,0122 & 0,0053 & - \\
\hline P_7 & 0,0068 & 0,0151 & 0,0017 & - & 0,0141 & 0,0165 & 0,0083 & - \\
\hline P_8 & 0,0067 & 0,0167 & 0,0018 & - & 0,0066 & 0,0154 & 0,0082 & - \\
\hline
\end{tabular}

Table 5. Comparison of the results of simulation and experimental tests

\begin{tabular}{||c|c|c|c|c||}
\hline $\begin{array}{c}\text { Designation } \\
\text { ofstudy }\end{array}$ & Extra capacitance & $\begin{array}{c}\text { Averagepressurep } \\
{[\mathrm{b} a \mathrm{r}]}\end{array}$ & $\begin{array}{c}\text { Peak to peak pressure } \\
\mathrm{p}_{1 \_ \text {PTP }}[\mathrm{bar}]\end{array}$ & Results source \\
\hline P_1 & No & 60,63 & 0,23 & Experiment \\
\hline m_P_1 & No & 60,30 & 0,123 & Simulation \\
\hline P_2 & Yes & 60,40 & 0,24 & Experiment \\
\hline m_P_2 & Yes & 60,30 & 0,152 & Simulation \\
\hline
\end{tabular}


reinforcement of pressure pulsation with higher frequencies by the discharge line.

Further research shall also focus on the way of setting the discharge pressure aiming at the reduction of the potential external interferences. The simplest method would be using the adjustable throttle valve in order to set the discharge pressure.

\section{Acknowledgement}

The presented studies were conducted with usage of the equipment in the Hydrostatic Drives Laboratory belonging to the EMT

Systems Ltd.

References

1. Bosch Rexroth AG. Hydraulik. Grundlagen und Komponenten. Lohr a. Main 2003 (in German).

2. Buchacz A, Płaczek M. Damping of Mechanical Vibrations Using Piezoelements, Including Influence of Connection Layer's Properties on the Dynamic Characteristic. Solid State Phenomena 2009; 147-149: 869-875, http://dx.doi.org/10.4028/www.scientific.net/SSP.147149.869.

3. Chalamowski M. Diagnostic susceptibility of Hydraulic Systems. Scientific Papers of the Maritime University in Szczecin 2004; 73 (1): 117-127.

4. da Costa Bortoni E., Almeida R. A., Viana A. N. C. Optimization of parallel variable-speed-driven centrifugal pumps operation. Energy Efficiency 2008; 1 (3): 167-173, http://dx.doi.org/10.1007/s12053-008-9010-1.

5. Dymarek A, Dzitkowski T. Active reduction of identified machine drive system vibrations in the form of multi-stage gear units. Mechanika 2014; 20 (2): 183-189.

6. Gendarz P. Bildung von geordneten Konstruktionsfamilien unter Anwendung von Ähnlichkeitsgesetzen. Forschung im Ingenieurwesen 2013; 3-4 (77): 105-115, http://dx.doi.org/10.1007/s10010-013-0167-1.

7. Gidziński T. Damage caused by errors in exploitation of vane pumps. Hydraulic and Pneumatic 2006; 1: 5-8.

8. Klarecki K., Hetmanczyk M.P., Rabsztyn D. Influence of the selected settings of the controller on the behavior of the hydraulic servo drive. Mechatronics - Ideas for Industrial Application. Advances in Intelligent Systems and Computing 2015; 317: 91-100, http://dx.doi. org/10.1007/978-3-319-10990-9 9.

9. Klarecki K., Hetmanczyk M.P., Rabsztyn D. The influence of volumetric performance settings of a multi-piston pump on parameters of forced vibrations. Vibroengineering Procedia 2014; 3: 76-81.

10. Kudźma Z. Damping pressure and noise pulsation in transient and established conditions in hydraulic systems. Publishing House of Wroclaw University 2012.

11. Kudźma Z. Dynamic properties of hydraulic hoses. Hydraulic and Pneumatic 2005; 6: 14-17.

12. Kudźma Z., Palczak E., Rutanski J., Stosiak M. Selected problems in exploitation of machines with hydrostatic drive. Mining Machines 2009; 4: 3-8.

13. Kunz A., Gellrich R., Beckmann G., Broszeit E. Theoretical and practical aspects of the wear of vane pumps Part A. Adaptation of a model for predictive wear calculation. Wear 1995; 181-183 (2): 862-867.

14. Kunz A., Gellrich R., Beckmann G., Broszeit E. Theoretical and practical aspects of the wear of vane pumps Part B. Analysis of wear behaviour in the vickers vane pump test. Wear 1995; 181-183 (2), 868-875, http://dx.doi.org/10.1016/0043-1648(94)07087-3.

15. Lisowski E., Panek M. CFD modeling method of vanes working in the vane pump. Eksploatacja i Niezawodnosc - Maintenance and Reliability 2004; 2: 36-41.

16. Mucchi E., Agazzi A., D'Elia G, Dalpiaz G. On the wear and lubrication regime in variable displacement vane pumps. Wear 2013; 306, (1-2): 36-46, http://dx.doi.org/10.1016/j.wear.2013.06.025.

17. Osiecki A. Hydrostatic drives. Warsaw: WNT, 2014.

18. Roskowicz M., Jastrzębski G. Evaluation of the possibility of diagnosing aircrafts hydraulic systems. WAT Bulletin 2009; 4 (LVIII): 335-349.

19. Stryczek S. Hydrostatic drive. Warsaw: WNT, 1995 (in Polish).

20. Wszolek G., Czop P., Skrobol A., Slawik D. A nonlinear, data-driven model applied in the design process of disc-spring valve systems used in hydraulic dampers. SIMULATION Transactions of the Society for Modeling and Simulation International 2013; 89 (3): 419-431, http:// dx.doi.org/10.1177/0037549712441976.

21. Wszolek G., Czop P., Slawik D. Development of an Optimization Method for Minimizing Vibrations of a Hydraulic Damper. SIMULATION Transactions of the Society for Modeling and Simulation International 2013; 89 (9): 1073-1086, http://dx.doi. org/10.1177/0037549713486012.

22. Yuan J., Yuan S. Prediction of performance for dissimilar centrifugal pumps coupled in series or in parallel. Drainage and Irrigation Machinery 2004; 22 (6): 1-4.

23. Zarzycki Z. Modeling of the hydraulic dynamic properties of closed conduits. Comparison of models with distributed parameters with lumped parameters models. Journal of Theoretical and Applied Mechanics 1989; 27(4): 625-634.

\section{Klaudiusz KLARECKI}

Dominik RABSZTYN

Mariusz Piotr HETMANCZYK

Faculty of Mechanical Engineering, The Silesian University of Technology

Institute of Engineering Processes Automation and Integrated Manufacturing Systems

ul. Konarskiego 18A, 44-100 Gliwice, Poland

E-mail: klaudiusz.klarecki@polsl.pl,dominik.rabsztyn@polsı.pl, mariusz.hetmanczyk@polsl.pl 